\title{
HAJI DI BONTONOMPO KABUPATEN GOWA TINJAUAN SOSIAL EKONOMI
}

\author{
Hajj in Bontonompo Gowa Regency: \\ Social Economy Study
}

Abd.Kadir Ahmad

Balai Penelitian Agama Makassar

Jl. AP. Pettarani No. 72 Makassar

Email: kadirahmad56@yahoo.co.id

Naskah diterima tanggal 3 Mei 2013. Naskah direvisi tanggal 12 Juni 2013. Naskah disetujui tanggal 1 Juli 2013

\begin{abstract}
Abstrak
Di Sulawesi Selatan, studi aspek sosial dan ekonomi haji belum pernah dilakukan, padahal berhaji bukan hanya meliputi aspek keagamaan akan tetapi juga kedua aspek tersebut. Pertanyaan yang ingin dijawab adalah bagaimanakah haji mengekspresikan diri melalui status dan peran-peran sosial pada masyarakat dan sumber-sumber ekonomi apa yang dimiliki para haji untuk dapat dipahami sebagai orang mampu (istitha')? Tujuan yang ingin dicapai adalah mengetahui status dan peran sosial dan latar belakang ekonomi sebagai akibat dari kehajian pada masyarakat pedesaan. Konsep yang digunakan adalah modal sumberdaya manusia, modal sosial, dan modal ekonomi dari Fukuyama, dan teori hubungan keberagamaan dan etosekonomi dari Max Weber. Dengan metode wawancara, angket dan dokumentasi, ditemukan para haji di Bontonompo memiliki modal sumber daya manusia yang lebih baik di atas rata-rata penduduk setempat dilihat dari aspek latar belakang pendidikan dan pekerjaan. Dari segi ekonomi para haji memiliki sumberdaya ekonomi yang jamak, selain pendapatan dari status PNS, mereka juga memiliki sejumlah areal lahan, perusahaan batu bata, perdagangan, dan ternak, baik secara sendiri-sendiri maupun akumulatif. Sumber daya sosial menunjukkan haji cenderung dipercaya untuk menempati posisi-posisi publik dan privat di berbagai bidang yang ada di pedesaan.
\end{abstract}

Kata kunci: haji, peran sosial, ekonomi

\begin{abstract}
Hajj does not only include religious but also social and economic aspects. However, there was no study on social and economic aspects of hajj in South Sulawesi. The article tried to answer the question on how hajj was expressed in social status and role and what the resource that makes a person able to go to hajj (istitha')? The article tried to describe the social status and role and the economic background of hajj in study target. Concept related to human resource, social economy, and economic capital of Fukuyama, and religious relation and economic ethos from Max Weber were used. Interview, documentation and inquiry helped to reveal the fact that people with hajj title in Bontonompo had higher human resource than other local residents, either in their education or job. Based on economic aspect, some of the hajj had many resources, his or her job sometimes was civil servant but he or she also had land, or did trading, or raised cattle either alone or in a group. A person with hajj title also, socially, tends to be relied upon to hold public and private position.
\end{abstract}

Keywords: hajj, role, and economic aspect

\section{PENDAHULUAN}

$\mathrm{D}$ alam rangka perencanaan kebijakan di bidang perhajian sebagai penunjang pembangunan keagamaan, maka penelitian tentang kehajian di Indonesia perlu dilakukan. Sumber informasi mengenai haji adalah melalui statistik, baik di tingkat Kabupaten maupun provinsi. Namun demikian, statistik sebagai sumber informasi hanya menyajikan informasi yang amat 
terbatas. Alasan lain mengapa studi mengenai haji ini perlu dilakukan di Sulawesi Selatan, karena arus jemaah haji dari daerah ini terus meningkat dari tahun ke tahun. Termasuk dalam situasi krisis ekonomi sekalipun. Tahun 2012 ini, daftar tunggu calon jamaah haji Sulsel telah mencapai 187.000 orang, yang kalau sesuai dengan quota sekarang daftar tunggu sampai 2025. (http://www.iphi.web. $\mathrm{id} / 2012 / 06 / 02$ ).

Jumlah tersebut dipastikan terus bertambah, seiring tingginya minat masyarakat untuk menunaikan ibadah haji. Hal ini menandakan bahwa 'pergi haji' adalah merupakan fenomena kehidupan keagamaan dan kemasyarakatan yang amat penting dalam kehidupan masyarakat Islam. Meski amat penting, masalah kehajian belum tersentuh secara proporsional dalam studi ilmiah. Padahal berhaji menandakan suatu pelaksanaan ibadah yang secara langsung terkait dengan dimensi sosial dan ekonomi. Haji dengan demikian tidak saja bermakna ritual tetapi juga simbol status sosial.

Sebagai indikator keagamaan, haji merupakan ekspresi dari ketaatan terhadap salah satu kewajiban dalam ajaran Islam, yaitu rukun kelima. Sebagai indikator ekonomi, haji hanya dapat dilaksanakan jika seseorang mampu memenuhi sejumlah dana untuk (Ongkos Naik Haji) ONH dan biaya sosial lainnya. Sebagai indikator, sosial karena haji telah menjadi simbol status yang nilainya amat tinggi di tengah masyarakat.

Berdasarkan pemikiran di atas, maka haji merupakan suatu tindakan keagamaan yang baik langsung maupun tidak, membawa kepada terjadinya transformasi dalam kehidupan keagamaan, transformasi ekonomi, dan transformasi sosial. Pembahasan yang diangkat dalam artikel ini, pertama dampak kehajian (sebagai haji) kepada perilaku keagamaan baik secara individual pada diri haji itu sendiri maupun terhadap masyarakatnya. Dalam hal ini, ingin diketahui peran-peran sosial keagamaan apa yang dimainkan oleh seseorang pascahaji dalam masyarakatnya. Kedua latar belakang ekonomi haji, melalui pemahaman terhadap sumber-sumber pendapatan dan penghidupan haji, sebagai penggambaran dari pemenuhan syarat istitha untuk berhaji.

Artikel ini merupakan hasil penelitian di masyarakat Desa di Kabupaten Gowa, Sulawesi Selatan, tepatnya di Kelurahan Bontonompo. Bontonompo dipilih sebagai kasus karena merupakan daerah berlatar belakang sejarah komunitas Islam yang sudah tua, sejak masuknya
Islam di Sulawesi Selatan. Salah satu bukti arkeologis ditemukan sebuah gaukang (benda pusaka komunitas) dalam bentuk panji (bendera) dan bekas masjid tua yang kemudian disebut masjid Katangka sebagai masjid pertama di Gowa. Daerah ini juga memiliki populasi haji relatif besar, untuk ukuran pedesaan.

Cikal bakal Kelurahan Bontonompo merupakan transformasi dari Desa Bontonompo. Daerah ini terletak di Kabupaten Gowa, 25 km di sebelah selatan Kota Makassar. Termasuk bagian dari Kerajaan Gowa sebelum berdirinya republik ini, Bontonompo menempati posisi bate ana'karaeng. Bate adalah satuan wilayah pemerintahan di bawah kerajaan. Secara harfiah menunjukan wilayah ini dijadikan otoritas anak raja, boleh jadi sebagai tempat pengkaderan untuk persiapan memasuki posisi penting di pusat kerajaan. Dalam posisi seperti itu, Bontonompo dipandang menyerupai bate. Setidaknya, demikianlah keadaan sejak tahun 1320 ketika Kerajaan Gowa mulai berdiri atas persetujuan kelompok kaum yang disebut Kasuwiyang-Kasuwiyang dan merupakan kerajaankerajaan kecil lokal (Daeng Patunru, 1969).

Salah satu legitimasi status Bontonompo dalam sejarah lokal adalah kepemilikan apa yang disebut gaukang atau kalompoang (kebesaran) dalam bentuk panji atau bendera. Panji ini amat khas Islam dilihat dari isinya. Terbuat dari kain, berukuran $2 \mathrm{x} 1$ meter dengan dasar warna biru, sekeliling pinggir bendera bertuliskan ayat kursi dengan warna tulisan kuning emas. Pada setiap sudut bendera tertulis masing-masing nama Khulafaur Rasyidin. Di bagian tengah dengan warna hitam adalah gambar pedang bersilang. Gaukanga atau jimaka (azimat) ini disimpan dan dipelihara di sebuah rumah tua, peninggalan keluarga Anrongguru Bontonompo.

Bontonompo dipimpin oleh seorang Anrongguru. I Juseng Daeng Mallingkai adalah Anrongguru pertama dan I Patarai Daeng Ma'ruppa yang menjabat 1961-1987, Anrongguru terakhir bersamaan dengan berakhirnya era keanrongguruan dan peralihan ke status Desa Bontonompo. namun demikian, keturunan I Juseng daeng Mallingkai generasi ke-12 masih memegang kepemimpinan sebagai lurah. Ia mengetuai organisasi Lembaga Adat Kerukunan Keluarga Kare I Juseng Daeng Mallingkai Anrongguru ri Bontonompo (LAK3IYDM).

Kelurahan ini dilewati aliran irigasi Sungai Jeneberang untuk daerah Bontonompo dan sekitarnya. Sistem pengairan yang memadai 
membuat usaha pertanian masyarakat berjalan dengan baik. Transportasi ke daerah ini dapat diakses dengan mudah, karena berada tepat pada jalur jalan Negara yang menuju ke selatan Sulawesi Selatan, seperti ke Takalar, Bantaeng, Jeneponto, Bulukumba, Selayar, dan Sinjai.

Kajian penelitian yang dilakukan merupakan kajian antropologis dan sosiologis mengenai haji sebagai fenomena keagamaan. Pendekatan yang digunakan adalah fungsionalisme, oleh Geertz (1992) disebut sebagai banyak mewarnai kajian antropologis dan sosiologis mengenai peranan agama dalam masyarakat. Menurut Mattulada (1989) Ilmu-ilmu agama, pada segi-seginya yang menyangkut masalah sosial, dapat diteliti dan diamati dengan menggunakan piranti ilmiah. Seperti kata Wallerstein (1997), tidak percaya bahwa teradat monopoli-monopoli pengetahuan, begitu pula zona-zona pengetahuan yang merupakan wilayah eksklusif orang-orang tertentu dengan gelar-gelar tertentu universitas. Kajian multi disiplin sangat memungkinkan. Secara metodologis studi ini merupakan kajian kualitatif dan kuantitatif deskriptif, jenis penelitian yang bersifat penggambaran mengenai gejala-gejala sosial secara lebih mendalam.

Data untuk kajian dilakukan dengan dengan angket. Akan tetapi karena tidak ada jaminan bahwa masyarakat desa dapat mengisi angket secara tertulis, maka pengumpulan data juga dilakukan dengan metode wawancara. Demikian juga pendataan awal mengenai rumah tangga haji dilakukan sebelumnya. Karena hanya rumah tangga yang teradapat hajilah yang dijadikan sebagai sampel. Selain kedua jenis data tersebut, juga dilakukan penelusuran dokumen resmi pemerintah kelurahan yang memuat informasi kepemilikan tanah dan usaha warga Kelurahan setempat.

Jenis data yang dihasilkan dalam penelitian ini adalah data kualitatif dan kuantitatif. Data kualitatif berkaitan dengan fenomena sosial ekonomi. Pengolahan data kuantitatif dan penyajiannya dilakukan dengan statistik deskritif berupa persentase (Sugiyono,1999). Statistik deskriptif adalah statistik yang berfungsi mendeskripsikan atau memberi gambaran terhadap obyek yang diteliti melalui data sampel atau populasi sebagaimana adanya, tanpa melakukan analisis dan membuat kesimpulan yang berlaku secara umum.

\section{PEMBAHASAN}

Studi mengenai aspek sosial ekonomi kehajian belum pernah dilakukan secara mendalam, kalaupun ada belum terpublikasikan secara luas, sehingga belum diketahui kalangan luas termasuk komunitas ilmuwan. Oleh karena itu, studi ini masih merupakan langkah awal (eksploratif), sehingga tentu saja acuan-acuan teoritis untuk membangun landasan teori dari penelitian ini masih amat menyulitkan.

Emile Durkheim melihat agama sebagai produk kehidupan kolektif; kepercayaan dan ritus agama juga memperkuat ikatan-ikatan sosial di mana kehidupan kolektif itu bersandar. Dengan kata lain hubungan antara agama dan masyarakat memperlihatkan saling ketergantungan yang erat. Dalam hubungannya dengan moralitas sebagai dasar bagi terwujudnya tatanan masyarakat, ia memperkenalkan istilah collective conscience. Menurutnya, the totality of belief and sentiments common to average citizens of the same society forms a determinate system which has its own life; one may call it the collective conscience (Johnson, 1986).

Durkheim melihat adanya perbedaan collective conscience pada masyarakat yang memiliki solidaritas mekanik (masyarakat tradsional) dan masyarakat dengan solidaritas organik (masyarakat modern). Perbedaan itu terjadi pada empat dimensi, yaitu: volume (banyaknya orang yang mendukung collective conscience); intensitas (sejauhmana dalamnya setiapindividu merasakan halitu); rigiditas (bagaimana hal itu dibatasi); dan muatan (bentuk kesadaran kolektif). Pada masyarakat dengan tipe solidaritas mekanik, collective conscience mencakup semua masyarakat dan anggota masyarakat bersangkutan (volume); dipercaya dengan intensitas tinggi; berlaku secara rigid (ketat, kaku), dan sangat bermuatan religius. Sebaliknya pada masyarakat organik (modern) collective conscience terbatas dari segi pendukung; intensitasnya rendah, kurang rigid, dan muatannya lebih mengandung moral individualisme. Durkheim juga memperkenalkan apa yang disebutnya collective representations yaitu norma-norma dan nilai-nilai kolektivitas spesifik seperti keluarga, negara, institusi keagamaan dan pendidikan (Ritzer, 1992).

Disinilah haji, dengan menggunakan perspektif Durkheim, muncul sebagai suatu bentuk collective conscience (kesadaran bersama) yang lahir dari kesadaran kolektif masyarakatnya. Collective 
conscience diartikan sebagai totalitas kepercayaankepercayaan dan sentimen-sentimen bersama yang rata-rata ada pada masyarakat yang sama. Dengan kata lain, meskipun haji adalah merupakan bagian dari ajaran yang oleh orang Islam dipahami sebagai bagian dari perintah Allah bukan dari manusia, namun ketika ajaran itu sudah bersentuhan dengan manusia, maka pada waktu yang sama ia lalu menjadi bagian dari kebudayaan, yang oleh Geertz diilustrasikan sebagai jaringan-jaringan makna (Geertz, 1992).

Dalam kesadaran bersama itu peranan collective representation menjadi sangat penting. Durkheim mengartikan collective representations yaitu norma-norma dan nilai-nilai kolektivitas spesifiksepertikeluarga, negara, institusi keagamaan, dan pendidikan yang dimiliki masyarakat. Peranan penting dari lembaga keagamaan disini adalah sebagai sarana sosialisasi dari ajaran agama. Dan dalam lembaga keagamaan inilah berperan tokoh agama sebagai pemegang kendali lembaga keagamaandan sekaligus perwakilan darimasyarakat beragama. Karena sistem perwakilan inilah maka sering terjadi ide dasar mengenai agama tidak seperti apa yang menjadi kenyataan di masyarakat. Dalam kasus haji misalnya, pemahaman masyarakat lokal mengenai haji, amat tergantung pada tokoh agama seperti ulama, ustadz, atau pengurus masjid, sebagai sumber belajar dan jaringan informasi masalah kehajian. Akan tetapi perlu diwaspadai juga adanya false consciousness (kesadaran semu). Menurut Marx, orang-orang dalam masyarakat dengan sistem kelas (class society) percaya terhadap banyak hal yang sebenarnya tidak benar, tetapi lebih menyerupai sebuah 'ideologi', yang tujuan utamanya adalah untuk melegitimasi dan melestarikan posisi mereka yang sedang memegang kontrol. Marx melihat agama sebagai suatu contoh yang jelas dalam kasus ini (Wallace and Alison Wolf, 1980).

Dalam buku The Protestant Ethic and the Spirit of Capitalism, Max Weber mengungkapkan tesisnya bahwa aspek-aspek tertentu dalam etika Protestan merupakan perangsang yang kuat dalam meningkatkan pertumbuhan sistem ekonomi kapitalis dalam tahap-tahap pembentukannya. Pengaruh yang merangsang ini dapat dilihat sebagai suatu elective affinity (konsistensi logis dan pengaruh motivasional yang bersifat mendukung secara timbal balik), antara tuntutan etis tertentu yang berasal dari kepercayaan Protestan dan pola-pola motivasi ekonomi yang perlu untuk pertumbuhan sistem kapitalisme (Johnson, 1986).
Sebagai suatu ibadah dengan keharusan pemenuhan syarat kemampuan secara ekonomi, haji dapat dijelaskan lewat teori tentang adanya hubungan etis antara agama dengan ekonomi. Dari teori ini dapat dipahami adanya ransangan dari faktor agama terhadap kreativitas ekonomi. Haji dengan biaya yang tidak kurang banyaknya dapat diduga sebagai faktor pendorong bagi masyarakat untuk bekerja keras guna memenuhi persyaratan tersebut, sampai yang bersangkutan betul-betul berhasil malaksanakan haji. Sekali seseorang telah sampai kepada status ekonomi yang lebih baik, ia tidak dengan suka rela ingin menurunkan tingkat status tersebut. Meski sudah haji akan tetap mempertahankan kebiasaan bekerja keras. Dari sudut teoritis hal ini membawa kita pada persoalan kemungkinan hubungan yang saling mendukung antara kenyataan rohaniah dengan perilaku. Dalam hal ini ada semacam etos kerja atau sumber motivasi seseorang dalam berbuat, dan itu dapat dicari melalui agama (Abdullah, 1979).

Dalam penelitian ini juga digunakan konsep community capital (modal komunitas), sebuah komunitas dikenal beberapa bentuk modal, yaitu modal manusia (human capital), modal sumberdaya alam (natural capital), modal ekonomi (economic capital), dan modal sosial (social capital). Human kapital, adalah kemampuan personal (pendidikan/ pengetahuan, kesehatan, keahlian dan keadaan terkait lainnya). Natural kapital adalah modal alam misalnya sinar matahari, cuaca, air, flora dan fauna, sumber energi, tanah, dan lain-lain. Economic capital adalah asset ekonomi dan asset finansial. Sedangkan social capital adalah kepercayaan, resiprositas, norma sosial lainnya, partisipasi dalam jaringan, dan proaktif (Hasbullah, 2006).

\section{Modal Manusia}

Meski posisinya merupakan rukun kelima dalam urutan rukun Islam, di kalangan masyarakat Islam, kedudukan haji dipandang sesuatu yang sangat khusus dan bergengsi. Disebutkan khusus karena selain haji tidak ada ibadah mahdlah yang lain yang dikaitkan sebagai identitas diri seorang muslim. Itulah sebabnya, orang yang haji dan belum haji mudah dikenali. Di Bontonompo, haji tersosialisasi secara sosiologis karena orang yang melakukannya harus dipanggil sesuai dengan predikat kehajiannya. Dalam dialeg bahasa lokal seorang haji dipanggil Daeng Ngajji yang sebenarnya berasal dari Daeng (sebagai panggilan penghormatan) dan haji. Daeng Haji kemudian menjadi Daeng Ngajji. 
Demikian mudahnya haji itu dikenal sehingga siapa pun akan mengenal seseorang yang sudah haji, termasuk tahun berhaji. Dengan cara seperti itulah peneliti berhasil merekam nama-nama haji yang ada di Keluarahan Bontonompo saat ini. Mereka tersebar di empat lingkungan di kelurahan tersebut. Jika ditotal pada keempat lingkungan yang ada di Kelurahan Bontonompo terdapat 108 orang haji dengan komposisi menurut jenis kelamin 38 laki-laki dan 80 perempuan atau jumlah perempuan lebih dari dua kali lipat jumlah haji laki-laki. Gejala sosiologis haji memperlihatkan fenomen yang memperkuat adanya pengaruh variabel jenis kelamin terhadap realitas berhaji.

Fenomena ini memerlukan penjelasan, karena pada galibnya ketaatan seseorang terhadap agama cenderung menekankan pentingnya posisi lakilaki, yang dipandang sebagai pemimpin keluarga. Terlepas dari penjelasan dari pertimbangan agama, secara sosiologis, keluarga di Bontonompo cenderung mendahulukan istri daripada suami untuk menunaikan ibadah haji. Secara ekonomi tentu tidak relevan dijadikan penjelasan, karena posisi laki-laki dan perempuan dalam pemanfaatan hasil usaha bersama tidak pernah menjadi persoalan penting.

Pertanyaannya mengapa harus perempuan didahulukan, padahal dalam Islam laki-laki adalah pemimpin? Ini harus kembali kepada kajian antropologi yang melihat budaya semacam mistar, dimana manusia mengarahkan perilakunya. Masyarakat desa seperti Bontonompo memiliki budaya pesta terkait dengan siklus hidup. Pada setiap pesta yang menjadi pelaku utama yang menduduki bagian depan teater kehidupan adalah perempuan. Laki-laki meramunya di belakang layar dan yang menyuguhkannya adalah perempuan.

Sebagai pemain dalam pentas budaya, perempuan menempati posisi yang menentukan harkat dan martabat keluarga tetapi juga kekuatan dari sebuah pesta. Semakin banyak haji yang menjadi pelaku, maka akan semakin legitimate pesta tersebut. Di sanalah arti kehadiran para haji perempuan.

Dari sisi pembelajaran agama, perempuan juga adalah mereka yang paling aktif berpartisipasi dalam kongregasi dan kelompok-kelompok pembelajaran semacam majelis taklim. Di dalam pembelajaran ini kesadaran berhaji didoktrinasi terus menerus sehingga memperlihatkan temuan bahwa tingkat kemantapan penghayatan dan pengamalan agama bagi perempuan lebih mendalam dari laki-laki.
Dalam konteks ini perempuan lebih siap baik secara mental dan spiritual untuk melaksanakan haji ketimbang laki-laki. Disini bertemulah dua alasan, yakni alasan manifes bermotif keagamaan, dan alasan laten untuk memenuhi harapan sosial dalam pentas budaya.

Perempuan dengan haji telah memasuki kesadaran bersama dan tidak terlepas dari peran collective representation yaitu dari lembaga keagamaan khususnya lembaga-lembaga pengajian sebagai sarana sosialisasi dari ajaran agama. Dalam lembaga keagamaan inilah berperan tokoh agama sebagai pemegang kendali lembaga keagamaan dan sekaligus perwakilan dari masyarakat beragama. Karena sistem perwakilan inilah maka sering terjadi ide dasar mengenai agama tidak seperti apa yang menjadi kenyataan di masyarakat. Dalam kasus haji, misalnya pemahaman masyarakat lokal mengenai haji amat tergantung pada tokoh agama atau pengurus haji, sebagai sumber belajar dan jaringan informasi masalah kehajian.

Aspek lain dari modal manusia adalah pendidikan. Tema pendidikan dipandang memiliki kontribusi terhadap seseorang menunaikan ibadah haji. Hal itu disebabkan karena haji memerlukan standar pengetahuan untuk memahami kaifiat haji dan tata cara berhaji. Minimal seseorang harus tahu membaca. Itulah sebabnya tema pendidikan dipandang penting dalam pelaksanaan haji.

Trend latar belakang pendidikan haji di Bontonompo adalah setingkat SLTA. Ini ditunjukkan oleh sebanyak 53,70 \% dari mereka menamatkan pendidikan di tingkat SLTA. Tidak ada relevansi haji dengan latar belakang pendidikan. Ternyata hanya 6 orang haji $(10,34 \%)$ di antaranya yang menamatkan pendidikannya di Madrasah Aliyah. Tentu saja harus dipahami, sebagaimana kewajiban agama yang lain, tingkat ketaatan seseorang tidak selalu berkorelasi dengan latar belakang pendidikan. Hal itu disebabkan oleh kenyataan bahwa pengetahuan agama sebagai prasyarat keberagamaan yang baik (barangsiapa yang dikendaki kebaikan diberikan pemahaman dalam agama) dapat diperoleh melalui proses belajar di luar sekolah, misalnya lewat pengajian-pengajian, ceramah keagamaan, atau pembacaan sendiri.

Sepanjang keikutisertaan para haji pada aktivitas pembelajaran keagamaan, penelitian ini menunjukkan 80 orang haji (74\%) aktif sebagai pengurus atau anggota kegiatan sosial keagamaan. Keanggotaan dan kepengurusan kegiatan 
keagamaan menjadi media seseorang belajar dan bersosialisasi serta melakukan internalisasi ajaran agama. Termasuk di antaranya majelis taklim, kepengurusan masjid, kepengurusan mayat, pengelolaan pendidikan dasar Al quran (Taman Baca Al quran), kepengurusan hari-hari besar Islam, dan pengurus remaja masjid.

Dengan demikian dapat disimpulkan bahwa para haji di Bontonompo adalah mereka yang memiliki kemampuan relatif untuk menunjang kehidupan sosial keagamaan, terutama dari aspek kepemilikan modal pendidikan yang memadai diukur dari rata-rata pendidikan warga masyarakat Bontonompo. Kecenderungan tingkat pendidikan haji kompatibel dengan komposisi pendidikan warga masyarakat Bontonompo, yaitu besarnya partisipasi haji pada tingkat pendidikan menengah. Kecenderungan ini memperlihatkan kuatnya kelas menengah terdidik pada struktur sumberdaya manusia masyarakat desa di Bontonompo. Pada sisi ini pula para haji menempati posisi agen perubahan penting dalam komunitas.

\section{Modal Ekonomi Haji \\ Akumulasi Modal Ekonomi}

Sejarah berhaji di Bontonompo berlangsung sejak Islam berkembang di daerah itu. haji paling awal yang dikenal masyarakat setempat adalah $\mathrm{H}$. Hasan, qadhi pada era pemerintahan Anrongguru Poli, pertengahan abad 19. Ia bersama Anrongguru mendirikan masjid tertua di daerah itu yang kemudian disebut masjid Katangka, mengambil nama masjid pertama di Lakiung. Pada tahun 1965 haji Ranti, anak tertua Anrongguru Sija menunaikan ibadah haji, ketika transpor haji masih menggunakan kapal laut dari Indonesia ke Saudi Arabia. Sekarang ini, haji tertua yang masih hidup dan dapat ditelusuri waktu berhajinya adalah haji yang menunaikan ibadah wajib tersebut tahun 1980.

Hj. Maemuna Daeng Mayang, sekarang berusia 77 tahun, perempuan yang melaksanakan haji tahun 1980, atau 34 tahun silam. Ia seorang ibu rumah tangga, ketika menunaikan ibadah haji ia berusia 42 tahun, dua orang haji yang hampir bersamaan adalah $\mathrm{H}$. Nahasan Daeng Ngawing (72 tahun) melaksanakan haji tahun 1982. Ia seorang pensiunan Pegawai Negeri Sipil (PNS) yang tentu saja ketika ia menunaikan ibadah haji semasa aktif sebagai PNS, ketika ia berusia 40 tahun. Ia memiliki 5 orang tanggungan dalam keluarganya, meski hal itu tentu saja tidak menjadi beban berat baginya sebagai pensiunan, karena ia sendiri memiliki standar ekonomi untuk menyokong keluarganya selain uang pensiun. Dari catatan kelurahan setempat ditemukan bahwa haji Nahasan Daeng Ngawing memiliki sawah 1 ha dan kebun seluas 30 are. Selain itu ia juga memiliki usaha batu bata dengan modal gaji ditambah penghasilan dari hasil usaha pertanian, perkebunan dan industri kecil batu bata, tidak sulit baginya untuk memenuhi ONH. ONH tahun 1980 sebesar Rp. 1.490.000,- termasuk uang bekal kembali untuk jemaah sebesar Rp, $20.000,-$.

Hj. Sadariah Daeng Ngati (66 tahun), adalah satu di antara warga Bontonompo yang menunaikan haji tahun 1982 bersamaan dengan Daeng 'Ngajji' Ngawing. Ia juga seorang PNS yang ketika menunaikan ibadah haji masih berusia 36 tahun. Dengan 5 orang anggota keluarga yang masuk dalam tanggungannya, kehidupan ekonomi Hj. Daeng Ngati bertumpuh pada uang pensiun dan sawah 30 are. Waktu itu pemerintah menetapkan, untuk musim haji tahun 1982/1983 besarnya ONH dengan pesawat udara sebesar Rp. 2.110.000,termasuk uang bekal kembali untuk jemaah sebesar Rp. 30.000,- Hal tersebut didasarkan pada Keputusan Presiden Republik Indonesia Nomor 8 Tahun 1982 Tentang Besarnya ONH Tahun 1982/1983.

Memerlukan waktu tiga tahun lamanya warga Bontonompo melakukan usaha untuk dapat menunaikan ibadah haji lagi. Pada tahun 1985 dua orang warga melepaskan kerinduannya ke tanah suci yaitu H. Muh. Yasin Daeng Timung (75 tahun) dan Hj. Mannitoa Daeng Ngati (72 tahun). Keduanya sekarang berstatus pensiunan PNS. Ketika menunaikan haji keduanya masih aktif sebagai PNS. Meski berstatus PNS, Daeng Timung masih memiliki sumber pendapatan yang lain berupa 2,5 ha sawah dan 19 are kebun. Ia juga memelihara binatang ternak dan masih memiliki usaha dalam bentuk lain. Akumulasi modal haji tersebut membuatnya tidak memiliki beban berarti bagi keluarga yang harus ditanggungnya yang sekarang masih ada dua orang. Bermodalkan penghasilan dari bekerja sebagai PNS dan dari usaha itulah Daeng Timung membiayai ONH. Demikian halnya dengan Hj. Mannitoa Daeng Ngati. Wanita dengan tanggungan keluarga yang cukup besar ini (7 orang) ia menunaikan haji dengan modal penghasilan dari gaji ditambah akumulasi penghasilan dari sawah 1,15 ha dan kebun 4 are yang dimilikinya. Bahkan ia pun masih memiliki binatang ternak dan usaha 
lain. Ia mengaku berkat gaji dan tabungan maka ia dapat mengongkosi biaya haji. Keduanya harus mengeluarkan ONH dengan pesawat udara sebesar Rp.3.212.000,- termasuk uang bekal kembali untuk jamaah sebesar Rp.15.000,- berdasarkan Keputusan Presiden Republik Indonesia Nomor 7 Tahun 1985 tentang besarnya ONH tahun 1985/1986.

Dalam masa 4 tahun berikutnya hanya 2 orang dari warga yang sempat melaksanakan ibadah haji, masing-masing Hj. Saadiah Dg Kanang (70 tahun) berhaji tahun 1987 dan Hj. Rosmawati Dg Lino (72 tahun) pada tahun 1989. Hj. Kanang adalah seorang ibu rumah tangga yang menanggung 4 orang. Ia memiliki modal haji berupa sawah 1 ha dan kebun 0,5 ha. Ia pun masih memiliki usaha ekonomi dalam bentuk lain. Ia mengongkosi haji dengan modal usaha dan hasil pertanian yang dimilikinya. Besaran $\mathrm{ONH}$ dengan pesawat udara waktu itu berkisar Rp. 4.560.000,- termasuk uang bekal kembali untuk jamaah sebesar Rp. 15.000,- besaran itu didasarkan pada Keputusan Presiden Republik Indonesia Nomor 2 Tahun 1987 Tentang Besarnya ONH Tahun 1987/1988.

Sementara Hj. Rosmawati Daeng Lino berprofesi PNS dan sekarang sudah pensiun. Menanggung 5 orang, ia memiliki sawah 70 are dan kebun 11 are, di samping binatang ternak dan usaha ekomomi yang lain. Dari warisan yang dimilikinya ditambah penghasilan dari gaji membuatnya mampu membiayai ONH pada tahun 1989, ketika ONH yang harus dikeluarkan berkisar pada besaran Rp. 5.150.00,- termasuk uang bekal kembali untuk jamaah sebesar Rp. 20.000,-. Besaran itu didasarkan pada Keputusan Presiden Republik Indonesia Nomor 1 Tahun 1989 Tentang Besarnya ONH Tahun 1989.

Praktis dalam 10 tahun (1980-1989) warga Bontonompo yang menunaikan ibadah haji sebanyak 7 orang. Hal ini berbeda dengan trend kehajian dasawarsa 1990-1999 dan seterusnya. Pada 10 tahun kedua tersebut jumlah orang berhaji di daerah tersebut sebanyak 27 orang, naik 4 kali lipat dari dasawarsa sebelumnya. Lonjakan drastis terjadi 10 tahun berikutnya fenomena berhaji semakin trendi dengan 59 orang warga yang menunaikan haji pada kurun waktu 2000-2009, lebih dari dua kali lipat dasawarsa sebelumnya. Kecenderungan itu kelihatannya akan terus meningkat dari tahun ketahun, pada tahun 2010 dan 2011 saja sudah 18 warga yang menunaikan haji. Pada tahun 2012 lonjakan di luar ekspektasi mencapai 10. 109 orang membutuhkan 17 tahun untuk memberangkatkan mereka ke tanah suci (Tribun Timur, 27/9/2012).

Fenomena menarik dari gejala naik haji di Bontonompo adalah adanya fenomena 5 tahunan. Sejak tahun 2000 setiap 5 tahun terjadi lonjakan warga yang menunaikan haji. Tahun 2000 terdapat 12 orang warga yang menunaikan ibadah haji, angka yang amat berbeda dari tahun-tahun sebelumnya. Tahun 1995, trend lima tahunan itu mulai kelihatan, dimana sejak tahun1990-1994 hanya 5 orang warga yang berangkat haji dalam kurun waktu 5 tahun. Akan tetapi pada tahun 1995 tiba-tiba warga yang berhaji sebanyak 4 orang dalam tahun itu saja.

Lima tahun kemudian (2000) sebanyak 12 orang melaksanakan haji, meningkat dari paling tinggi 6 orang setahun dalam tahun 1996-1999. Bahkan pernah terjadi tidak ada warga yang menunaikan haji dalam tahun itu (1999). Setelah tahun 2000, warga yang berhaji kemudian turun kembali sama seperti tahun sebelumnya untuk kemudian terjadi lonjakan lagi pada hitungan 5 tahun berikutnya pada tahun 2005 , terdapat 11 orang warga yang menunaikan ibadah haji. Dinamika itu kemudian mengalami penurunan kembali pada tahun-tahun setelah itu dan paling banyak 7 orang yang menunaikan haji pada tahun 2007. Bahkan sempat mencapai titik terendah pada tahun 2008 hanya 2 orang warga berhaji.

Seperti sebelumnya terjadi lagi loncatan pada tahun 2010 warga berhaji sebanyak 13 orang. Kelihatannya fenomena 5 tahunan itu akan masih berlangsung sesudah itu, karena pada tahun 2011, warga yang berhaji mengalami penurunan kembali sampai ke jumlah 5 orang saja.

Hampir setiap tahun, $\mathrm{ONH}$ atau sekarang disebut BPIH (Biaya Penyelenggaraan Ibadah Haji) naik antara 7-10 \%. Penyebabnya bermacam-macam misalnya kenaikan harga pelayanan ibadah haji (biaya pemondokan, kesehatan, dan transportasi) yang ditetapkan negara Arab Saudi, harga minyak (harga minyak mempengaruhi biaya avtur pesawat, sehingga mempengaruhi pula biaya tiket), serta kurs rupiah yang melemah terhadap dollar AS, terakhir ini penyebab yang paling menakutkan yang bisa memicu naiknya ONH hingga berlipat-lipat.

ONH pada tahun 1970 hanya Rp. 182.000,tahun 1988 hampir dua puluh tahun setelahnya ONH sebesar Rp. 4.780.000,-; pada $1998 \mathrm{ONH}$ senilai Rp 8.805.000,-; tahun berikutnya 1999-2000, setelah terjadi krisis ekonomi besar yang melanda Indonesia dan dunia, biaya haji naik hingga Rp. 
21,5 juta. Pada 2008, ONH menjadi 32.400.000,pada tahun 2011 pemerintah menetapkan BPIH rata-rata sebesar US\$ 3.537 atau $\mathrm{Rp} 30.771 .900 /$ orang. Besarnya BPIH ini berbeda-beda di antara 11 embarkasi yang ada di seluruh Indonesia disesuaikan dengan faktor jarak atau geografis.

Besarnya BPIH bervariasi setiap tahunnya sesuai dengan fluktuasi nilai tukar valuta asing dan kondisi perekonomian. Pengalaman selama 30 tahun ini menunjukkan bahwa BPIH mengalami fluktuasi tergantung kondisi perekonomian. Sebagai contoh, efek krisis 1998, BPIH pada 1999 meroket menjadi Rp. 27.373.000,- dari hanya Rp. 8.805.000,- pada 1998. Hal ini menyebabkan banyak calon jamaah haji yang terpaksa mengurungkan niatnya berhaji sehingga jumlah jamaah haji Indonesia pada tahun 1999 turun drastis hingga hampir sepertiganya.

Apakah faktor mekanisme 5 tahunan itu merupakan gejala ekonomi atau sesuatu yang bersifat instrumental dalam pelaksanaan haji di masyarakat, masih memerlukan penelusuran. Keputusan Presiden Republik Indonesia Nomor 8 tahun 1979, menetapkan ONH tahun 1980 sebesar Rp. 1.490.000,- termasuk uang bekal kembali untuk jemaah sebesar Rp, 20.000,-.

Lima tahun kemudian (1985) ONH diputuskan berdasarkan Keputusan Presiden Republik Indonesia Nomor 7 Tahun 1985 tentang besarnya ONH tahun 1985/1986 dengan pesawat udara adalah sebesar Rp.3.212.000,- termasuk uang bekal kembali untuk jamaah sebesar Rp.15.000,-. Interval waktu antara 1980 dengan 1985 ONH berlipat dua kali lebih. Lima tahun kemudian untuk musim haji Tahun 1990 $\mathrm{ONH}$ dengan pesawat udara adalah sebesar Rp. 5.320.000,- termasuk uang bekal kembali untuk jamaah sebesar Rp. 20.000,-.

Pertambahannya untuk jarak waktu 5 tahun sebelumnya tidak sampai dua kali lipat seperti kelipatan kurun waktu 1980-1985. Hal itu diputuskan berdasarkan Keputusan Presiden Nomor 6 Tahun 1990 Tanggal 26 Januari 1990. Lima tahun kemudian, ONH ditetapkan oleh Presiden melalui Keppres Nomor 62 Tahun 1994 Tanggal 23 Agustus 1994 tentang Besarnya ONH Tahun 1995. Dalam Kepres tersebut disebutkan Besarnya ONH dengan pesawat udara untuk musim haji tahun 1995 adalah sebesar Rp. 7.070.000, termasuk uang bekal di Arab Saudi (living cost) sebesar SR 1.700 (SA. Ryal seribu tujuh ratus) untuk jamaah haji yang diberikan kepada setiap jamaah pada saat pemberangkatan dan uang bekal kembali ke daerah sebesar Rp. 50.000, yang diberikan kepada setiap jamaah pada saat pemulangan di setiap embarkasi.

Pada tahun 2000 biaya penyelenggaraan ibadah haji diturunkan secara signifikan dari Rp. 27.373.000 atau US\$ 3.538 pada tahun 1999 menjadi Rp. 17.758.000,- atau US\$2.138 pada tahun 2000. Meski mengalami penurunan perbandingan BPIH tahun 2000 dengan ONH tahun 1995 cukup jauh, yakni dari Rp. 7.070.000,- menjadi Rp.17.758.000,- selisih sepuluh jutaan lebih. Itupun setelah mengalami penurunan dari tahun sebelumnya (1999), BPIH waktu itu mencapai Rp. 27.373.000,- atau US\$ 3.538. Tahun $2005 \mathrm{ONH}$ ditetapkan sebesar Rp. 23,5 juta, dan tahun 2010 Biaya Perjalanan Ibadah Haji (BPIH) tahun 2010 akhirnya diputuskan sebesar US\$3.342 atau setara dengan sekitar Rp. 30 juta dengan kurs sebesar US\$. 9052.

\section{Biaya Upacara Prahaji}

Orang yang akan berhaji tidak hanya memerlukan biaya untuk memenuhi pembayaran ONH tetapi juga biaya sosial berupa ongkos upacara prahaji. Biaya sosial ini terkait dengan pelaksanaan upacara syukuran atau manasik haji. Manasik haji, belakangan ini sudah dilakukan oleh Kementerian Agama, secara teratur dan rutin dalam frekuensi pertemuan tertentu menjelang keberangkatan. Setidaknya tahun-tahun terakhir ini minimal 4 kali pertemuan di tingkat kecamatan dan 1 kali di tingkat kabupaten. Bagi mereka yang bergabung ke Kelompok Bimbingan Ibadah Haji (KBIH) akan mengikuti bimbingan manasik secara regular yang sebagai salah satu servis dari lembaga tersebut kepada jamaahnya.

Fenomena manasik haji dalam bentuk keramaian dengan mengundang banyak orang merupakan fenomena baru. Sebelum manasik dalam bentuk ini, pemantapan manasik haji sebelumnya lebih banyak dilakukan dalam kelompok kecil atau bahkan hanya merupakan urusan calon haji dengan seorang guru di kampung.

Bagi calon haji setelah era kapal laut, yang ditandai dengan semakin banyaknya warga yang menunaikan ibadah haji, model manasik pun mengalami pergeseran. Acaranya lebih merupakan acara syukuran untuk mengumpulkan kerabat, tetangga dan masyarakat setempat, untuk turut acara selamatan tersebut. Kalau pun acara itu disebut manasik, lebih merupakan formalitas, karena 
sebelumnya aktivitas manasik sudah dilaksanakan secara bertingkat dari kelompok, kecamatan, sampai kabupaten.

Pelaksanaan syukuran, selamatan, atau manasik hal tersebut memerlukan ongkos, kalau melibatkan banyak orang (peneliti menyebutnya biaya sosial). Upacaranya sendiri sudah dianggap bagian dari prosesi pergi haji, sehingga terinternasilisasi melalui proses inkulturasi menjadi sebuah tradisi haji. Pada tahapan seperti ini upacara ini dapat disebut ritual prahaji. Biaya sosial untuk ritual prahaji tersebut bervariasi menurut era dan kemampuan calon haji.

Pelaksanaan syukuran untuk haji umumnya dilakukan setelah shalat zuhur, dan sebagian kecil sesudah ashar. Sebagaimana biasanya sebuah kenduri atau pesta, undangan tidak datang begitu saja, tetap saja ada bawaan baik berupa uang maupun bingkisan berharga lainnya, untuk mengurangi beban calon haji. Bahkan di antara mereka berharap apa yang diberikannya dapat turut terbawa ke tanah suci. Ini juga untuk sebuah motivasi tabarruk bagi pemberinya. Bahkan dalam masyarakat setempat pemberian sesuatu memiliki nilai ekonomi, merupakan resiprositas yang sudah terkonstruksi secara sosial.

\section{Sumber Pembiayaan}

Realitas di lapangan menunjukkan modal utama untuk pembiayaan seseorang berhaji di Bontonompo adalah hasil pendapatan dari pekerjaan sebagai PNS, dari hasil pendataan haji yang dilakukan peneliti terdapat 67 orang yang berstatus haji dan masih hidup sekarang ini berlatar belakang pekerjaan PNS, baik masih aktif maupun sudah menjalani masa pensiun. Itu berarti $61,26 \%$ dari total 109 orang haji di kelurahan tersebut.

Gambaran pekerjaan para haji yang paling dominan adalah PNS (61,11 \%), menyusul ibu rumah tangga, pengusaha, dan petani. Artinya lebih dari separuh haji di pada masyarakat desa tersebut terdiri dari mereka yang memperoleh pendapatan tetap dari pemerintah. Sudah menjadi kenyataan di masyarakat bahwa warga masyarakat yang memiliki margin ekonomi yang longgar di tengah masyarakat transisi seperti Indonesia adalah pegawai pemerintah. Status sosial seseorang pun terangkat dengan memiliki status tersebut. Hal itu didasarkan pada keyakinan bahwa mereka yang berpenghasilan dari pegawai negeri bukan saja mendapatkan kepastian penghidupan sehari-hari tetapi kepastian akan jaminan hari tua.

Dengan demikian, langkah untuk melakukan investasi pribadi termasuk investasi agama lebih memungkinkan. Hal itu ditunjang lagi oleh kenyataan bahwa pegawai negeri tidak sematamata menyandarkan pendapatan dari penghasilan bulanan itu saja, tetapi juga pada umumnya mereka pun masih memiliki penghasilan dari sumber lain, misalnya pemilikan sawah, kebun, ternak dan usaha sampingan, bahkan usaha yang spesifik daerah seperti usaha batu bata. Kenyataan demikian, merupakan ciri masyarakat desa seperti Bontonompo. Pegawai negeri hanya salah satu jenis pekerjaan tetapi basisnya adalah kehidupan pertanian.

Kelihatannya sebanyak 82,41 \% haji memiliki lahan dengan luas bervariasi. Sebanyak hampir 35 $\%$ memiliki lahan kurang dari 0,5 ha. Ini dimaknai sebagai kepemilikan lahan relatif kecil. Sementara masing-masing $24 \%$ lebih adalah para haji dengan luas lahan 0,5-1 ha, dan mereka yang lahannya mencapai lebih dari 1 ha. Kepemilikan lahan 0,5-1 ha dikategorikan sebagai kepemilikan lahan berukuran sedang, sementara 1 ha lebih menunjukkan kepemilikan lahan dalam ukuran luas.

Kenyataan tersebut menunjukkan apa pun pekerjaannya, para haji di masyarakat desa Bontonompo $80 \%$ lebih adalah mereka yang memiliki kemampuan untuk menunjang hidupnya secara berlapis antara lain di samping memiliki pendapatan dari bidang usaha atau pekerjaan lain juga masih memiliki suplai berupa hasil dari produktivitas lahan yang dimiliki. Khusus fenomena haji berlatar belakang PNS atau pensiunan PNS.

Dari 66 PNS atau pensiunan PNS yang berstatus haji, terdapat 83 orang (33\%) pegawai dengan kepemilikan lahan mulai dari ukuran kurang dari 0,5 ha sampai di atas 1 ha. Hanya 16,66\% yang tidak memiliki lahan. Pegawai negeri diuntungkan oleh keadaan bahwa dengan basis tradisi pertanian, mereka memiliki peluang untuk melakukan seving dari hasil pemasukan pendapatan rutin setiap bulan. Untuk belanja sehari-hari bagi keperluan rumah tangga biasanya disuplai dari hasil produksi pertanian.

Akumulasi dari pendapatan tetap mereka bahkan dijadikan modal untuk pengembangan usaha di bidang pertanian dan di sektor lain. Kemudahan memperoleh pinjaman dari bank 
dengan jaminan dokumen kepegawaian yang dimiliki salah satu faktor menguntungkan PNS untuk investasi, termasuk membiayai ONH. Selain itu, bagi PNS yang memasuki masa pensiun, uang tunai berupa Taspen, biasanya dijadikan modal tabungan haji.

Bukan hanya PNS yang memiliki modal ekonomi akumulatif, tetapi juga termasuk ibu-ibu rumah tangga. Ibu rumah tangga ini pun tidak selamanya tidak memiliki sumber pendapatan untuk diri dan keluarganya. Di lapangan, ternyata dari kalangan perempuan ini terdapat akumulasi modal ekonomi yang potensial.

Sesungguhnya gambaran para haji di Bontonompo hampir semuanya memiliki modal ekonomi dari pemilikan tanah. Dengan demikian, terjadi over lapping profesi di pedesaan seperti Bontonompo. Basis mereka adalah bertani namun bukan hanya para petani murni sebagai basis pekerjaannya, tetapijugasebagai PNSdan pengusaha. Maka semakin tinggi over lapping tersebut, semakin besar peluang untuk melaksanakan ibadah haji dari sudut pembiayaan.

\section{Modal Sosial}

Seseorang yang sudah menunaikan ibadah haji, maka namanya akan sangat dikenal di komunitasnya dan dari kalangan orang kebanyakan status sosialnya akan meningkat ke tingkat menengah. Hal ini ditandai dengan panggilan Daeng yang di dalam tradisi Makassar dialamatkan bagi kalangan masyarakat tu bajiq, kelas menengah, di bawah Karaeng (raja) dan di atas tu samaraq (orang biasa). Mobilitas vertikal terjadi dalam dinamika sosial masyarakat desa begitu seseorang berubah status keagamaan menjadi haji, ke status sosial yang lebih tinggi.

Dari aspek agama Islam, perubahan sosial ini merupakan refleksi dari ajaran Islam sebagaimana diindikasikan di dalam Al quran bahwa seseorang dengan iman yang baik akan meningkatkan derajatnya. Dari sudut pandang ilmu sosiologi agama dipandang kesadaran kolektif yang menjadikan masyarakat menjadi lebur di dalam kolektivitas berdasarkan kesadaran yang sama. Kesadaran tentang haji merupakan produk kehidupan kolektif yang bersumber dari sistem kepercayaan dan dikukuhkan melalui berbagai aktivitas ritual yang pada gilirannya memperkuat ikatan-ikatan sosial.

Seperti dijelaskan dalam kajian teoritis, Durkheim melihat adanya perbedaan collective conscience pada masyarakat yang memiliki solidaritas mekanik (masyarakat tradisional) dan masyarakat dengan solidaritas organik (masyarakat modern). Perbedaan itu terjadi pada empat dimensi yaitu volume, intensitas, rigiditas, dan muatan. Pada masyarakat dengan tipe solidaritas mekanik, collective conscience mencakup semua masyarakat dan anggota masyarakat bersangkutan (volume); dipercaya dengan intensitas tinggi; berlaku secara rigid (ketat dan kaku), dan sangat bermuatan religius. Sebaliknya pada masyarakat organik (modern) collective conscience terbatas dari segi pendukung; intensitasnya rendah, kurang rigid, dan muatannya lebih mengandung moral individualisme.

Penggunaan konsep modal sosial untuk pengertian peran sosial yang dimainkan para haji. Hal ini penting dikemukakan mengingat haji dipandang sebagai status yang diidamkan banyak orang. Sebagai status yang dicita-citakan, mereka yang berhasil mendudukinya dipandang orang pilihan dan dilengketi atribut yang khas.

Sebanyak 102 orang haji yang ada di Bontonompo aktif di masyarakat dengan peranperan sosial berbeda. Hanya menyisakan 6 orang saja yang tidak mengambil bagian di dalam lembagalembaga sosial dan atau keagamaan di kelurahan tersebut. Statusnya bervariasi, baik sebagai pengurus maupun sebagai anggota. Keterlibatan mereka di dalam lembaga-lembaga sosial dan pemerintahan di kategorikan ke dalam lembaga pemerintahan itu sendiri, lembaga keagamaan dan lembaga sosial di luar kedua kategori tersebut (umum).

Lembaga pemerintahan adalah struktur pemerintahan di tingkat kelurahan. Terdapat 7 orang haji yang menduduki jabatan dalam struktur formal pemerintah. Tingkatannya bervariasi mulai dari ketua RW, kepala lingkungan, sampai pada lurah, salah seorang haji warga masyarakat Bontonompo menjadi lurah di kelurahan lain. Mereka semuanya menduduki jabatan itu sebelum status haji.

Keterlibatan haji paling banyak kelihatan dalam urusan bersama dalam bidang keagamaan. Terdapat 80 orang haji $(74,07 \%)$ yang aktif di berbagai lembaga keagamaan tersebut. Kebanyakan (75 \%) dari mereka terlibat setelah menyandang status haji, dan $25 \%$ lainnya terlibat sejak sebelum haji. Lembaga keagamaan dimaksud umumnya bergerak pada kegiatan pencerahan jamaah, khususnya majelis taklim. Sebanyak 53 orang haji $(49,07 \%)$ yang aktif di majelis taklim setempat. Selain itu, peran sosial keagamaan lainnya yang 
diemban para haji adalah kepengurusan masjid (16 orang atau sekitar 6,04\%), imam lingkungan dan kelurahan 4 orang, sinoman (perkumpulan kepengurusan mayat) 4 orang, pengurus hari besar Islam, dan Badan Kordinasi Remaja Masjid.

Berdasar pada teori tentang fungsi agama, salah satu fungsi haji sebagai salah satu bentuk ritus adalah mempersatukan individu dalam kegiatan bersama dengan satu tujuan bersama dan memperkuat kepercayaan, perasaan dan komitmen moral yang merupakan dasar struktur sosial. Keterlibatan para haji pada kegiatan keagamaan menunjukkan cerminan kesadaran kolektif yang terbangun di kalangan mereka untuk mengambil bagian dalam lembaga keagamaan.

Kesadaran kolektif seperti itu, kelihatan masih kental sebagai ciri masyarakat desa. Dilihat dari aspek volume (banyaknya orang yang mendukung kegiatan keagamaan); intensitas (sejauhmana dalamnya setiap individu merasakan hal itu); rigiditas (bagaimana hal itu dibatasi); dan muatan (bentuk kesadaran kolektif). Pada masyarakat Bontonompo, kesadaran kolektif haji untuk terlibat dalam urusan keagamaan mencakup semua anggota dari komunitas haji bersangkutan (volume); bahwa haji dipercaya dengan intensitas tinggi dan berlaku secara rigid di dalam komunitas.

haji juga terlibat dalam peran-peran nonkeagamaan, seperti PKK bagi haji perempuan. Namun demikian, kebanyakan pengurusan PKK dirangkap oleh sebagian haji perempuan. Setidaknya ini terjadi bagi 15 pengurus dan atau anggota Badan Kontak Majelis Taklim. Peran nonkeagamaan tersebut, misalnya peran dalam kepengurusan koperasi, organisasi pertanian, dan tata kelola pengairan.

Fenomena rangkapan posisi sosial di kalangan para haji bukan hanya berlaku bagi haji perempuan, tetapi juga para haji laki-laki. H. Pata Daeng Romo, misalnya, selain kepala lingkungan ia juga menjabat Ketua BP3A. Demikian juga H. Muhammad Rudini Daeng Tunru merangkap 3 jabatan sosial sekaligus, yaitu imam kelurahan, ketua LPM, dan ketua pengurus masjid besar setempat. H. Abd. Rahman Daeng Sese, BA, merangkap dua jabatan bendahara, yaitu bendahara LPM dan bendahara pengurus masjid. Seorang lurah merangkap sebagai ketua PHBI setempat, atas nama H. Nahasan Daeng Ngawing. Seorang Lurah yang lain sekaligus menjabat ketua Koperasi Pelopor, atas nama $\mathrm{H}$. Hamdat Daeng Rala.
Selain itu, terdapat rangkapan jabatan yang lain, yaitu ketua BKMT dan sekretaris PKK dijabat orang yang sama, Hj. Zuhriyah Daeng Baji. ketua Sinoman juga dirangkap oleh yang sama dengan kepengurusan BKMT, atas nama Hj. Jima Daeng Jinne. ketua kelompok kerja PKK merangkap ketua kelompok kerja BKMT.

Fenomena akumulasi status dan peran sosial terjadi sedemikian rupa pada diri seseorang atau beberapa orang sehingga tidak ada posisi sosial penting di dalam masyarakat tanpa terjamah oleh seorang haji. Apakah pemberian kepercayaan oleh masyarakat kepada para haji untuk mengurusi kepentingan mereka diberikan atas pertimbangan 'sifat amanah' dari para haji, tentu masih harus didalami lebih jauh. Akan tetapi setidaknya fenomena ini menunjukkan adanya petunjuk ke arah sana.

\section{PENUTUP}

Beberapa simpulan penelitian sekitar modal manusia, modal ekonomi, dan modal sosial berhaji. Modal manusia atau SDM haji ditandai dominasi haji perempuan terhadap haji laki-laki dilihat dari segi jumlah. Hal ini tidak terlepas dari budaya lokal yang menempatkan perempuan sebagai pemeran dalam lakon pada front teater kehidupan masyarakat setempat. haji juga dipandang sebagai media mobilitas vertikal anggota masyarakat ke strata sosial lebih tinggi. Hal ini ditandai dengan labeling Daeng Ngajji kepada setiap orang yang sudah berhaji. Pada bagian ini juga haji ditandai trend segmen masyarakat terdidik. Setidaknya mayoritas haji merupakan orang-orang yang menamatkan pendidikan setingkat SLTA ke atas. Hanya sebagian kecil haji yang pendidikannya setingkat Sekolah Dasar.

Mayoritas haji berlatar belakang PNS atau pensiunan PNS. Pekerjaan lainnya adalah pengusaha, petani, dan ibu rumah tangga. Namun demikian, sumber utama pendapatan para haji adalah sektor pertanian. Hal itu ditandai dengan pemilikan lahan oleh hampir semua haji. Terjadi kecenderungan akumulasi modal ekonomi pada para haji di Bontonompo. Bagian terbesar dari para haji selain memiliki pekerjaan tetap, juga memiliki lahan, usaha batu bata, binatang ternak dan berbagai variasi usaha lainnya. Dari sisi ini, haji di Bontonompo dipandang memiliki standar kemampuan (istitha') ekonomi sebagai syarat haji. 
Modal sosial haji ditandai oleh peningkatan status menjadi Daeng Ngajji. Peningkatan status tersebut dengan segala nilai haji yang dikandungnya menyebabkan haji dipercaya untuk menduduki posisi-posisi sosial keagamaan, pemerintahan, dan posisi kemasyarakatan. Kebanyakan status atau posisi sosial penting di masyarakat dijabat oleh para haji. Seperti halnya akumulasi dalam bidang modal ekonomi, sejumlah haji tertentu juga cenderung menempati akumulasi status dan peran sosial di dalam masyarakat.

\section{UCAPAN TERIMA KASIH}

Ucapan terima kasih penulis kepada Lurah dan Imam di Kecamatan Bontonompo serta para haji yang tidak dapat penulis ucapkan satu persatu, atas partisipasi dan informasi sehingga penelitian ini berjalan dengan baik. Dan terkhusus ucapan terima kasih penulis kepada Tim Redaksi Al-Qalam yang telah menjadikan tulisan penulis menjadi salah satu bagian dalam edisi ini.

\section{DAFTAR PUSTAKA}

Abdullah, Taufik (editor). 1979. Agama, Etos Kerja dan Perkembangan Ekonomi. Jakarta: LP3ES.

Daeng Patunru, Abdurrazak. 1969. Sedjarah Gowa. Ujung Pandang: Jajasan Kebudajaan Sulawesi Selatan dan Tenggara.

Geertz, Clifford. 1992. 'Kebudayaan dan Agama' ditejemahkan oleh Budi Susanto, The Interpretation of Culture. Yogyakarta: Kanisius. 1992. 'Tafsir Kebudayan' di tejemahkan oleh Budi Susanto, The Interpretation of Culture. Yogyakarta: Kanisius.

Hasbullah, Jousairi. 2006. Social Capital. Jakarta: MR-United Press.

http://www.iphi.web.id/2012/06/02/daftar-tunggu- haji-sulsel-sampai-2025

Johnson, Doyle Paul. 1986. 'Sociological Theory' di tejemahkan oleh Robert M.Z.Lawang, Sosiologi Klasik dan Modern, Jilid I. Jakarta: PT.Gramedia.

Mattulada. 1989. 'Studi Islam Kontemporer (Sintesis Pendekatan Sejarah, Sosiologi, dan Antropologi dalam Mengkaji Fenomena Keagamaan)' dalam Taufik Abdullah dan M. Rusli Karim Metodologi Penelitian Agama. Yogyakarta: PT. Tiara Wacana.

Ritzer, George. 1992. Sociological Theory. USA: Mc Graw-Hill Inc.

Sugiyono. 1999. Statistika untuk Penelitian. Bandung: Alfabeta.

Tribun Timur, Media Harian Lokal tanggal 27/9/2012 mengenai Kuota Jamaah haji Indonesia

Wallace, Ruth,A and Alison Wolf. 1980. Contemporary Sociological Theory. USA: Prentice Hall Inc.

Wellerstein, Immanuel. 1997. Lintas Batas Ilmu Sosial. Yogyakarta: LKIS.

\section{Dokumen:}

Keputusan Presiden RI Nomor 6 Tahun 1990 Tanggal: 26 Januari 1990 Tentang Besarnya ONH Tahun 1991.

Keputusan Presiden RI Nomor 62 Tahun 1994 Tanggal 23 Agustus 1994 Tentang Besarnya ONH Tahun 1995.

Keputusan Presiden RI Nomor 1 Tahun 1989 Tentang Besarnya ONH Tahun 1989.

Keputusan Presiden RI Nomor 2 Tahun 1987 Tentang Besarnya ONH Tahun 1987/1988.

Keputusan Presiden RI Nomor 7 Tahun 1985 tentang besarnya ONH tahun 1985/1986.

Keputusan Presiden RI Nomor 8 Tahun 1982 Tentang Besarnya ONH Tahun 1982/1983. 